\title{
Cytokines induce airway smooth muscle cell hyperresponsiveness to contractile agonists
}

\author{
Yassine Amrani, Reynold A Panettieri Jr
}

A variety of cell types that reside in or infiltrate the inflamed submucosa potentially interact with airway smooth muscle cells and alter myocyte function. Eosinophils, macrophages and, particularly, lymphocytes are postulated as being critical in the initiation and perpetuation of the asthmatic response. One mechanism by which immunocytes exert their effects is the production of proinflammatory mediators that may act directly or indirectly on ASM cells. Several cytokine mRNAs and proteins have been detected within the airways of asthmatic subjects. The precise role of these cytokines in altering myocyte function has recently been the focus of a new line of research. Although cytokines have been reported to inhibit $\beta$ adrenergic receptor responsiveness in airway smooth muscle cells ${ }^{1}$ and alter mitogen induced myocyte growth, ${ }^{2}$ this article will review new evidence that suggests that cytokines also modulate contractile agonist induced calcium signalling in human airway smooth muscle cells.

Critical Care Divis

Hospital of the

University of

Pennsylvania,

Philadelphia,

Pennsylvania

19104-4283, USA

Y Amrani

R A Panettieri Jr

Correspondence to: Dr Y Amrani.

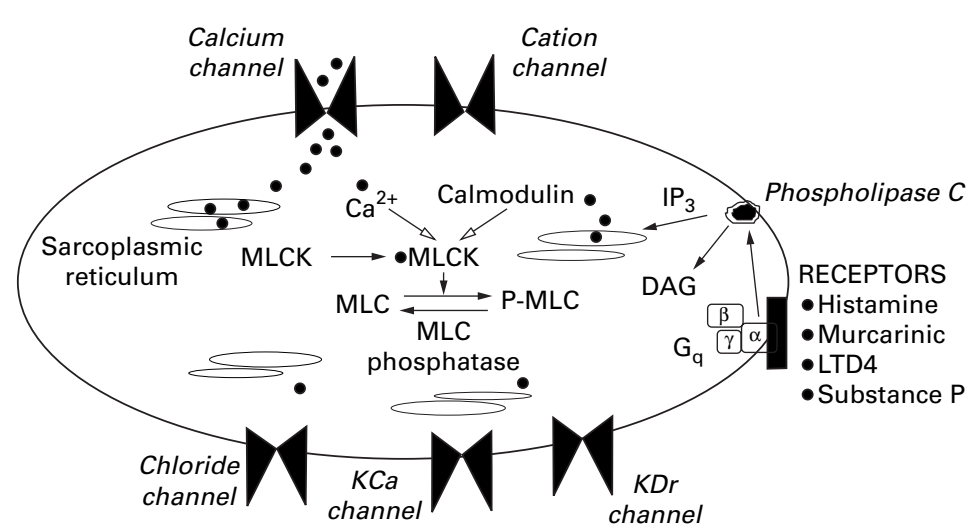

Figure 1 Major signalling molecules associated with contraction and relaxation of airway smooth muscle cells. Transmembrane proteins shown are $G$ protein coupled receptors with associated $G$ protein subunits $(\alpha, \beta$, and $\gamma)$ and plasmalemmal ion channels. $A G_{q}$ coupled receptor is ligand bound and the associated $G$ protein has undergone nucleotide exchange. The next step will be dissociation of the $\alpha$ and $\beta \gamma$ subunits, activation of phospholipase $C$, and release of intracellular calcium stores. Sources of calcium for contraction are also shown. Calcium permeates voltage dependent calcium channels and non-selective cation channels and is released by the sarcoplasmic reticulum (intracellular structures). Calcium molecules will bind calmodulin and activate myosin light chain kinase (MLCK), which will phosphorylate myosin light chains (MLC). Dephosphorylation occurs by myosin light chain phosphatase, which may be regulated during excitation-contraction coupling. Abbreviations include diacylglycerol $(D A G)$, inositol tris phosphate $\left(I_{3}\right)$, leukotriene $D_{4}\left(L T D_{4}\right)$, substance $P(S P)$ receptor, histamine receptor $\left(H_{1}\right)$, muscarinic receptors $\left(M_{2}\right)$, calcium activated potassium channel $\left(K_{C}\right)$, and delayed rectifying potassium channel $\left(K_{D R}\right)$. Reproduced from reference 47 with permission. monal, or due to the release of autocoids, results in a graded depolarisation and increase in tone in the muscle. Since excitatory and inhibitory stimuli are imposed on a tissue with little intrinsic contractile tone, the degree of muscle stimulation (and bronchodilation) will be the summated effect of bronchoconstrictor and bronchodilator stimuli.

Activation of an airway smooth muscle cell by a bronchoconstrictor induces a rapid rise in the intracellular concentration of calcium, associated with the release of intracellular calcium stores, to a peak level roughly 10 times higher than the resting level (from $100 \mathrm{nM}$ to more than $1 \mu \mathrm{M}$ at maximum agonist concentration) as shown in fig 1 . Following this peak the calcium level falls but remains raised as long as the contractile stimulus is present. The increased intracellular $\mathrm{Ca}^{2+}$ concentration results in the activation of the calcium/ calmodulin sensitive myosin light chain kinase, and the subsequent phosphorylation of the regulatory myosin light chain $\left(\mathrm{MLC}_{20}\right)$ at Ser 19. Phosphorylation of this residue by myosin ATPase activity initiates crossbridge cycling between myosin and actin. ATP binding, hydrolysis, and ADP release continue as long as $\mathrm{MLC}_{20}$ is phosphorylated; dephosphorylation terminates crossbridge cycling and relaxes smooth muscle. In addition to the regulation of tension by intracellular $\mathrm{Ca}^{2+}$, several mechanisms have been advanced to explain a lack of correlation between the intracellular $\mathrm{Ca}^{2+}$ concentration and tension between different modes of stimulation. The $G$ protein coupled regulation of myosin phosphatase may be an important mechanism by which "sensitisation" of myosin phosphorylation occurs. ${ }^{3}$

Evidence now suggests that tumour necrosis factor (TNF) and interleukin (IL)-1 $\beta$, cytokines found in the bronchoalveolar lavage fluid of patients with allergen induced asthma, ${ }^{4}$ may directly alter myocyte calcium homeostasis and render airway smooth muscle hyperresponsive to contractile agonists. Since airway smooth muscle is an essential effector cell modulating bronchoconstriction, and since calcium regulates airway smooth muscle cell contraction, interactions between cytokines, such as TNF $\alpha$ and IL-1 $\beta$ released from inflammatory cells, and calcium mobilisation may represent a mechanism underlying bronchial hyperresponsiveness in asthma. Amrani et $a l^{5}$ recently investigated whether TNF $\alpha$ modulated cytosolic calcium responses in airway smooth muscle stimulated with carbachol. Carbachol, ${ }^{56}$ bradykinin, and thrombin ${ }^{7}$ induced increases in intracellular $\mathrm{Ca}^{2+}$ concentrations were enhanced by TNF $\alpha$ and IL-1 in human airway smooth muscle. As shown in fig 2 , both phases 

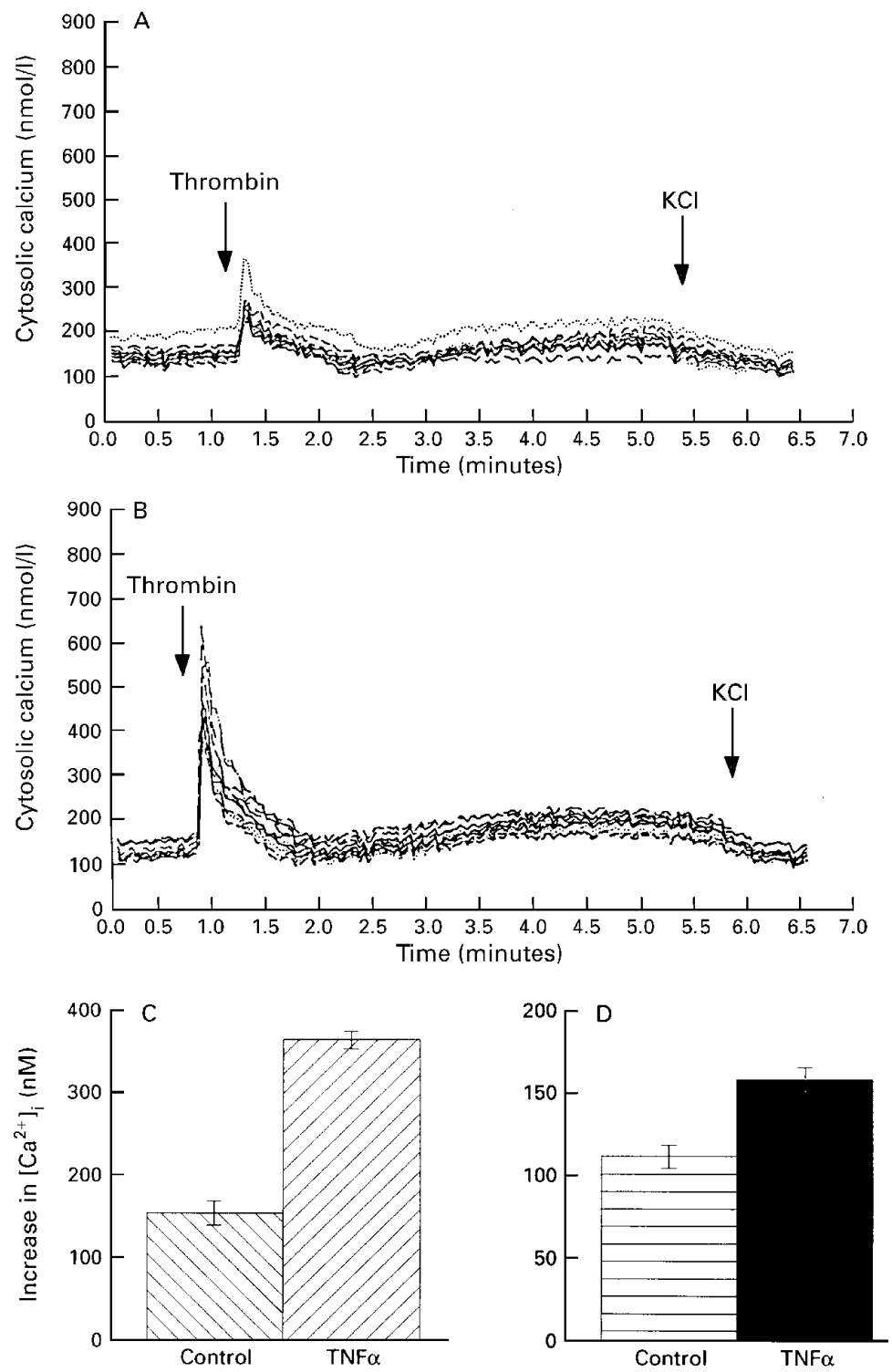

Figure 2 Typical $\mathrm{Ca}^{2+}$ traces from cells incubated in the absence $(A)$ or presence $(B)$ of $T N F a$ and respective values for the peak $(C)$ and sustained (D) $\mathrm{Ca}^{2+}$ phase from cells incubated in the absence or the presence of TNFa. Results are expressed as the net increase in intracellular concentration of $\mathrm{Ca}^{2+}$ over basal (unstimulated) levels. Values are means (SE) of four separate experiments and are significantly different from control (untreated cells; $p<0.01$ ). Statistical significance was determined using the unpaired Student's $t$ test. Reproduced from reference 7 with permission.

of thrombin induced calcium levels were affected by $\mathrm{TNF} \alpha$, suggesting increased calcium mobilisation both from intracellular and extracellular stores. ${ }^{7}$ Activation of TNFRp55, the predominant receptor expressed in human airway smooth muscle cells, and de novo protein synthesis were also found to be required for the effects of $\mathrm{TNF} \alpha$ on calcium mobilisation. ${ }^{67}$ The ability of $\mathrm{TNF} \alpha$ to alter the intracellular $\mathrm{Ca}^{2+}$ signals induced by a variety of different agonists suggested that this cytokine may "prime" airway smooth muscle cells for an increase in agonist responsiveness. This is an interesting finding since $\mathrm{TNF} \alpha$ can also induce the "primed" airway smooth muscle to become more contractile to the same agonists either in vivo $^{8-10}$ or in vitro. ${ }^{11}$
Whether both the phenomena of increased receptor mediated calcium responses and increased smooth muscle contractility are linked remains to be determined. However, the ability of IL-1 $\beta$ also to induce bronchial hyperresponsiveness ${ }^{12}$ in a similar manner to that of $\mathrm{TNF}^{7}$ suggests that cytokines may directly modulate airway myocyte calcium signalling and render the cell hyperresponsive to bronchoconstrictors. Further studies are needed to address whether this potential mechanism may induce bronchial hyperresponsiveness in asthma.

\section{Potential intracellular mechanisms altered by cytokines}

G PROTEIN MEDIATED SIGNAL TRANSDUCTION

Since $\mathrm{TNF} \alpha$ alone did not stimulate either a calcium response or phosphoinositide hydrolysis in human airway smooth muscle, $\mathrm{TNF} \alpha$ probably augments agonist induced increases in intracellular $\mathrm{Ca}^{2+}$ by directly affecting the coupling process of agonist receptors to downstream signalling events as shown in fig 3 . In human airway smooth muscle such receptors are known to be coupled to phospholipase C which catalyses the hydrolysis of phosphotidylinositol 4,5 bisphosphate, yielding inositol trisphosphate and diacylglycerol. ${ }^{13}$ Recent studies suggest that $\mathrm{TNF} \alpha$ significantly enhances phosphoinositide accumulation in response to bradykinin in human airway smooth muscle and epidermoid carcinoma cells. ${ }^{715}$ In addition, $G$ protein induced activation of adenylyl cyclase by isoproterenol or $G$ protein mediated arachidonic acid metabolism by bradykinin was also shown to be enhanced by $\mathrm{TNF} \alpha .{ }^{16}{ }^{17}$ In airway smooth muscle, however, $\mathrm{TNF} \alpha$ as well as IL-1 $\beta$ have been reported to inhibit isoproterenol stimulated activation of adenylyl cyclase. ${ }^{18}$

Cytokines have also been reported to modulate expression of $\mathrm{G}$ proteins. TNF $\alpha$ increases the amount, as well as the activity, of $\mathrm{G}$ proteins in several cell types including airway smooth muscle. ${ }^{17}{ }^{19-21}$ The finding that TNF $\alpha$ enhances calcium mobilisation in response to $\mathrm{NaF}^{7}$ an agent that bypasses membrane receptors and directly activates $G$ proteins, ${ }^{22}{ }^{23}$ supports the notion that TNF $\alpha$ acts directly at the level of G proteins rather than modifying the expression of contractile agonist receptors. This observation supports previous findings that, despite increased calcium signals to carbachol, $\mathrm{TNF} \alpha$ did not increase muscarinic receptor numbers. ${ }^{5}$ Finally, TNF $\alpha$ may also alter phospholipase C activity, as has been shown in a mouse fibrosarcoma cell line. ${ }^{24}$ Taken together, these studies show that cytokines modulate airway smooth muscle functions, not only by activating specific cytokine receptors, but also by dramatically amplifying the ability of other agonists to induce increases in the intracellular concentration of $\mathrm{Ca}^{2+}$.

INTRACELLULAR CALCIUM STORES

In many cell types the activation of calcium pumps directly regulates the calcium ion concentration both in the cytosol and in intracellular stores, either by extruding calcium 


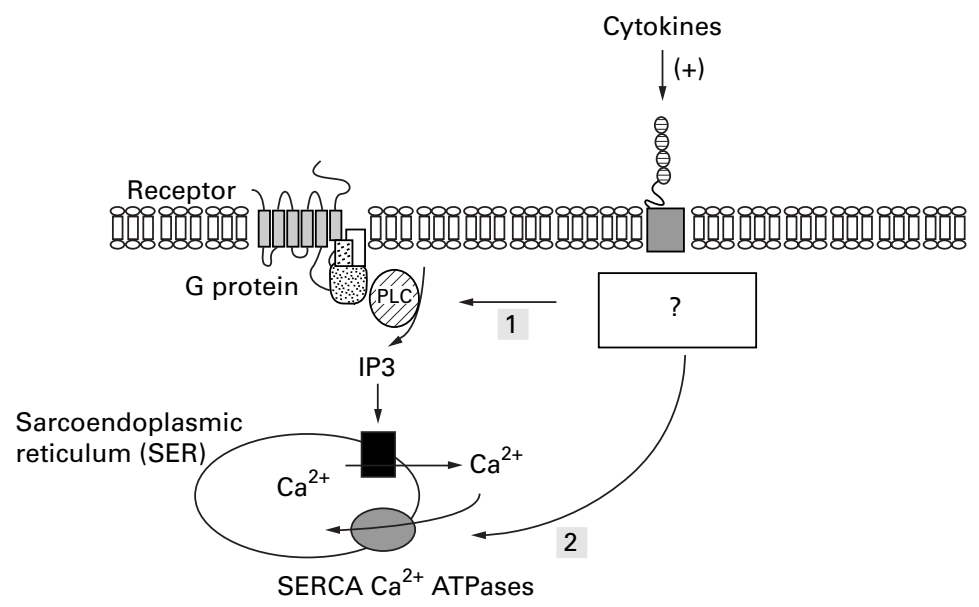

Figure 3 Potential sites for cytokine induced alterations in calcium homeostasis in human airway smooth muscle cells. This involves (1) the receptor/G protein/effector system and (2) the calcium regulatory proteins such as SERCA-type calcium pumps which function by pumping calcium from the cytosol to the internal stores. IP3 = inositol-1,4,5 trisphosphate; $P L C=$ phospholipase $C$. by cytokines and growth factors and may represent another pathway by which cytokines alter agonist induced calcium responses or modulate cell growth.

\section{Summary}

The important pathophysiological features of the airways in asthma include exaggerated narrowing to bronchoconstrictor agonists and attenuated relaxation to $\beta$ adrenoceptor stimulation. These physiological perturbations are associated with inflammation and remodelling of the airways, the latter including an increase in airway smooth muscle cell mass, disruption of the airway epithelium, and changes in the airway tissue extracellular matrix. Recent evidence suggests that cytokines, important molecules modulating airway inflammation, also directly decrease airway smooth muscle responsiveness to $\beta$ adrenergic agents, stimulate cytokine secretion, inhibit or promote airway smooth muscle proliferation, and "prime" airway smooth muscle to become hyperresponsive to bronchoconstrictors. Characterisation of the cellular and biochemical events that are involved in activation of airway smooth muscle is likely to be the major consideration in the design of future therapies for asthma. Because calcium is an essential regulatory element for cell growth and cell contraction, it is likely that alterations in calcium mobilisation may, in part, play a role in creating an airway smooth muscle phenotype that is hyperresponsive to contractile agonists. Further studies will be required to determine the precise mechanisms involved in cytokine modulation of calcium homeostasis in airway smooth muscle. respectively; and $\mathrm{SERCA}_{3}$ which is a nonmuscle isoform. ${ }^{27}$

Thapsigargin, a specific inhibitor of SERCA,${ }^{34-36}$ has been useful in defining the role of SERCA associated calcium pools in activating cellular signal transduction pathways. Thapsigargin sensitive calcium stores not only provide a source of calcium following bronchoconstrictor stimulation ${ }^{31}{ }^{32}$ but also appear to exert a profound control over cell proliferation and progression through the cell cycle. ${ }^{37} 38$ Calcium responses to thapsigargin, which triggers calcium signals by directly releasing intracellular stores, are potentiated by pretreating cells with $\mathrm{TNF} \alpha{ }^{6}{ }^{39}$ This effect may be due to an increased release of calcium, to an increase in calcium content, or to an increase in the number of SERCA-type calcium-ATPases sensitive to thapsigargin. Alternatively, cytokines may directly affect the intracellular $\mathrm{Ca}^{2+}$ concentration by altering the type of SERCA associated with the calcium stores. Interestingly, SERCA ${ }_{2 \mathrm{a}}$ protein and mRNA content are increased in a time dependent manner by TNF $\alpha{ }^{40}$ Several reports have also shown a modulation of SERCA-type $\mathrm{Ca}^{2+}$-ATPase expression in pathological conditions such as hyperthyroidism and hypertension. ${ }^{41-44}$ In other studies thyroid hormone, ${ }^{41}$ platelet-derived growth factor, ${ }^{45}$ and insulin growth factor ${ }^{46}$ upregulated transcription of the $\mathrm{SERCA}_{2}$ and SERCA $_{1}$ gene. Taken together, these studies suggest that calcium pumps that regulate intracellular calcium stores may also be altered
The study of airway smooth muscle cell function is a rapidly growing field and for this review we have tried to cite the most relevant publications. We therefore apologise to our colleagues working with airway smooth muscle cells in case their contributions were not cited. This work was supported in part by grants from the "Association Francaise pour la Recherche Therapeutique, AFRT," Paris (Amrani), the National Aeronautics and Space Administration (NRA-94-OLMSA-02) (Panettieri), the National Institutes of Health (R01-HL55301) (Panettieri), and a Career Investigator Award from the American Lung Association (Panettieri)

1 Shore SA, Laporte J, Hall IP, et al. Effect of IL-1 $\beta$ on responses of cultured human airway smooth muscle cells to bronchodilator agonists. Am 7 Respir Cell Mol Biol 1997;16:702-12.

2 Cohen MD, Ciocca V, Panettieri RA. TGF- $\beta 1$ modulates human airway smooth muscle cell proliferation induced by mitogens. Am f Respir Cell Mol Biol 1997;16:85-90.

3 Panettieri RA, Kotlikoff MI. Cellular and molecular mechanisms regulating airway smooth muscle cell physiology and eds. Fishman's pulmonary diseases and disorders, 3rd edn. New York: McGraw-Hill, 1998: 107-17.

4 Broide DH, Lotz M, Cuomo AJ, et al. Cytokines in symptoBroide DH, Lotz M, Cuomo AJ, et al. Cytokines in sympto-
matic asthma airways. 7 Allergy Clin Immunol 1992;89:95867 .

5 Amrani Y, Martinet N, Bronner C. Potentiation by tumor necrosis factor alpha of calcium signals induced by bradykinin and carbachol in human tracheal smooth muscle cells. Br F Pharmacol 1995;114:4-5.

6 Amrani Y, Panettieri R, Frossard N, et al. Activation of the $\mathrm{TNF} \alpha-\mathrm{p} 55$ receptor induces myocyte proliferation and modulates agonist-evoked calcium transients in cultured human tracheal smooth muscle cells. Am f Respir Cell Mol Biol 1996;15:55-63.

7 Amrani Y, Krymskaya V, Maki C, et al. Mechanisms underlying TNF $\alpha$ effects on agonist-mediated calcium homeostasis in human airway smooth muscle cells. Am 7 Physiol 1997;273:L1020-8.

8 Kips JC, Tavernier JH, Pauwels RA. Tumor necrosis factor (TNF) causes bronchial hyperresponsiveness in rats. Am

9 Wheeler AP, Hardie WD, Bernard GR. The role of cyclooxygenase products in lung injury induced by tumor necrosis factor in sheep. Am Rev Respir Dis 1992;145:6329. pharmacology. In: Fishman AP, Elias JA, Fishman JA, et al, 
10 Thomas PS, Yates DH, Barnes JP. Tumor necrosis factor-alpha increases airway responsiveness and sputum neutrophilia in normal human subjects. Am 7 Respir Crit Care Med 1995;152:76-80.

11 Pennings HJ, Kramer K, Bast A, et al. Tumour necrosis factor causes hyperresponsiveness in tracheal smooth muscle of the guinea-pig model in vitro. Eur Respir 7 1993;70:325s

12 Souhrada M, Souhrada JF. Potentiation of electrical and contractile response of sensitized airway smooth muscle to a specific antigen by interleukin-1 $\beta$. Am Rev Respir Dis 1993;147:A52.

13 Coburn RF, Baron CB. Coupling mechanisms in airway smooth muscle. Am F Physiol 1990;258:L119-33.

14 Giembycz MA, Raeburn D. Current concepts on mechanisms of force generation and maintenance in airway smooth muscle. Pulm Pharmacol 1992;5:279-97.

15 Sawutz DG, Singh SS, Tiberio L, et al. The effect of TNFo on bradykinin receptor binding, phosphotidylinositol turnover and cell growth in human A431 epidermoid turnover and cell growth in human A431 epider

16 Burch RM, Tiffany CW. Tumor necrosis factor causes amplification of arachidonic acid metabolism in response to interleukin-1, brady

17 Klein JB, Scherzer JA, Harding G, et al. TNF- $\alpha$ stimulates increased plasma membrane guanine nucleotide binding protein activity in polymorphonuclear leukocytes. F Leuko Biol 1995;57:500-6.

18 Emala CW, Kuhl J, Hungerford CL, et al. TNF $\alpha$ inhibits isoproterenol-stimulated adenylyl cyclase activity in cultured airway smooth muscle cells. Am f Physiol 1997;272: L644-50.

19 Reithmann C, Gierschik P, Werdan K, et al. Tumor necrosis factor- $\alpha$ up-regulates $\mathrm{G}_{\mathrm{i} \alpha}$ and $\mathrm{G}_{\beta}$ proteins and adenylyl cyclase responsive in rat cardiomyocytes. Eur $\mathcal{F}$ Pharmaco 1991;206:53-60.

20 Scherzer JA, Lin Y, McLeich KR, et al. TNF translationally modulates the expression of $G$ protein $\alpha_{\mathrm{i} 2}$ subunits in
human polymorphonuclear leukocytes. F Immunol 1997; human poly

21 Hakonarson H, Herrick DJ, Grunstein MM. Mechanism of imparied $\beta$-adrenoceptor responsiveness in atopic sensitized airway smooth muscle. Am f Physiol (Lung Cell Mol Physiol) 1995;269:L645-52.

22 Hall IP, Donaldson J, Hill SJ. Modulation of fluoroaluminate-induced inositol phosphate formation by increases in tissue cyclic AMP content in bovine tracheal smooth muscle. Br f Pharmacol 1990;100:646-50.

23 Hardy E, Farahani M, Hall IP. Regulation of histamine H1 receptor coupling by dexamethasone in human cultured airway smooth muscle. Br F Pharmacol 1996;118:1079-84

24 Machleidt T, Kramer B, Adam D, et al. Function of the $\mathrm{p} 55$ tumor necrosis factor receptor "death domain" mediated by phosphatidylcholine-specific phospholipase C. F Exp Med 1996;184:725-33.

25 Greeb J, Shull GE. Molecular cloning of the third isoform of the calmodulin-sensitive plasma membrane $\mathrm{Ca}^{2+}-$
transporting ATPase that is expressed predominantly in transporting ATPase that is expressed predominantly in
brain and skeletal muscle. $\mathcal{F}$ Biol Chem 1988;264:18569-

26 De Jaegere S, Wuytack F, Eggermont JA, et al. Molecular cloning and sequencing of the plasma-membrane $\mathrm{Ca}^{2+}$ pumps of pig smooth muscle. Biochem f 1990;271:655-60.

27 Lytton J, Maclennan DH. Molecular cloning of cDNA from human kidney coding for two alternatively spliced products of the cardiac $\mathrm{Ca}^{2+}$-ATPase gene. $\mathrm{F}$ Biol Chem 1988;263:15024-31.

28 Burk SE, Lytton J, MacLennan DH, et al. DNA cloning, functional expression, and mRNA tissue distribution of a third organellar $\mathrm{Ca}^{2+}$ pumps. F Biol Chem 1989;264:185618.

29 Eggermont JA, Wuytack F, Verbist J, et al. Expression of endoplasmic-reticulum $\mathrm{Ca}^{2+}$ pump isoforms and of phospholamban in pig smooth muscle tissues. Biochem $\mathcal{F} 1990$; 266:901-7.
30 Zarain-Herzberg A, MacLennan DH, Periasamy M. Characterization of rabbit cardiac sarco-endo-plasmic reticulum acterization of rabbit cardiac sarco-endo-plasmic re

31 Amrani Y, Da Silva A, Kassel O, et al. Biphasic increase in cytosolic free calcium induced by bradykinin and histamine in cultured tracheal smooth muscle cells: is the sustained phase artifactual? Naunyn-Schmied Arch Pharmacol 1994; 350:662-8.

32 Amrani Y, Magnier C, Wuytack F, et al. $\mathrm{Ca}^{2+}$ increase and $\mathrm{Ca}^{2+}$ influx in human tracheal smooth muscle cells: role of $\mathrm{Ca}^{2+}$ pools controlled by sarco-endoplasmic reticulum $\mathrm{Ca}^{2+}$-ATPase 2 isoform. Br 7 Pharmacol 1995;115:120410

33 Arai M, Otsu K, MacLennan DH, et al. Regulation of sarcoplasmic reticulum gene expression during cardiac and skeletal muscle development. Am f Physiol 1992;262:C614-30.

34 Thastrup O. Role of $\mathrm{Ca}^{2+}$-ATPases in regulation of cellular $\mathrm{Ca}^{2+}$ signalling, as studied with the selective microsomal $\mathrm{Ca}^{2+}$-ATPase inhibitor, thapsigargin. Agents Actions 1990; 29:8-15.

35 Thastrup O, Cullen PJ, Drobak BK, et al. Thapsigargin, a tumor promoter, discharges intracellular $\mathrm{Ca}^{2+}$ stores by
specific inhibition of the endoplasmic reticulum $\mathrm{Ca}^{2+}-$ ATPase. Proc Natl Acad Sci USA 1990;87:2466-70.

36 Takemura $\mathrm{H}$, Ohshika $\mathrm{H}$, Yokosawa $\mathrm{N}$, et al. The thapsigargin-sensitive intracellular $\mathrm{Ca}^{2+}$ pool is more important in plasma membrane $\mathrm{Ca}^{2+}$ entry than the IP3-sensitive intracellular $\mathrm{Ca}^{2+}$-pool in neuronal cell lines. Biochem Biophys Res Commun 1991;180:1518-26.

37 Short AD, Bian J, Ghosh TK, et al. Intracellular $\mathrm{Ca}^{2+}$ pool content is linked to control of cell growth. $\mathcal{F}$ Biol Chem 1993;90:4986-90.

38 Graber MN, Alfonso A, Gill DL. $\mathrm{Ca}^{2+}$ pools and cell growth: Arachidonic acid induces recovery of cells growtharrested by $\mathrm{Ca}^{2+}$ pool depletion. F Biol Chem 1996;271: 883-8.

39 Peiretti F, Fossat C, Anfosso F, et al. Increase in cytosolic calcium upregulates the synthesis of type I plasminogen activator inhibitor in the human histiocytic cell line. Blood 1996;87:162-73.

40 Amrani Y, Bobe R, Enouf J, et al. TNF $\alpha$ activates the transcription of SERCA gene in cultured human tracheal scription of SERCA
smooth muscle cells. Am $\mathcal{F}$ Respir Crit Care Med 1996;153: A164

41 Nagai R, Zarain-Herzberg A, Brandl CJ, et al. Regulation of myocardial $\mathrm{Ca}^{2+}$-ATPase and phospholamban mRNA expression in response to pressure overload and thyroid hormone. Proc Natl Acad Sci USA 1989;86:2966-70.

42 Levitsky DO, Clergue M, Lambert F, et al. Sarcoplasmic reticulum calcium transport and $\mathrm{Ca}^{2+}$-ATPase gene expression in thoracic and abdominal aortas of normotensive and spontaneously hypertensive rats. F Biol Chem 1993;268: 8325-31.

43 Papp B, Corvazier E, Magnier C, et al. Spontaneously hypertensive rats and platelet $\mathrm{Ca}^{2+}$-ATPases: specific up-regulation of the $97 \mathrm{kDa}$ isoform. Biochem $\mathcal{F}$ 1993;295: 685-90.

44 Bobe R, Bredoux R, Wuytack F, et al. The rat platelet $97-\mathrm{kDa} \mathrm{Ca}{ }^{2+}$-ATPase isoform is the sarcoendoplasmic
reticulum $\mathrm{Ca}^{2+}$-ATPase 3 protein. 7 Biol Chem 1994;269: 1417-24.

45 Magnier C, Papp B, Corvazier E, et al. Regulation of sarcoplasmic reticulum $\mathrm{Ca}^{2+}$-ATPases during platelet-derived growth factor induced smooth muscle proliferation. $\mathcal{F}$ Biol Chem 1992;267:15805-15.

46 Thelen MHM, Muller A, Zuidwijk MJ, et al. Differential regulation of the expression of fast-type sarcoplasmicreticulum $\mathrm{Ca}^{2+}$-ATPase by thyroid hormone and insulinlike growth factor-1 in the L6 muscle cell line. Biochem 7 1994;303:467-74.

47 Kotlikoff MI, Barnes PJ. Pharmacology of airway smooth muscle. In: Crystal RG, West JB, Weibel ER, Barnes PJ, eds. The Lung: Scientific Foundations, 2nd edn. Vol I. Philadelphia: Lippincott-Raven, 1996: 1345-54. 